\title{
SPEECH ACTS IN WEDDING CEREMONY WURUNG JUE OF DAYAK MA'ANYAN
}

\author{
Indra Perdana ${ }^{1}$, emzir ${ }^{2}$ \\ Universitas Palangka Raya \\ Universitas Negeri Jakarta \\ Indra.perdana@fkip.upr.ac.id ${ }^{1}$ \\ emzir@unj.ac.id ${ }^{2}$
}

\begin{abstract}
$\underline{\text { Abstract }}$
Wurung Jue is a series of events Process Dayak Customary Marriages Ma'anyan and Lawangan. Wurung jue Jue or bird is a symbol of faithful to their spouse. This research is a qualitative research. The main instrument in this study is the researchers themselves. Data collected over take the form of words or pictures instead of numbers. "The research data were retrieved through data collection techniques such as observation, interviews and documentation, namely the recording and record ripple used in ceremonies pernikahan.Hasil of this study were 1 ) ripple Ma'anyan Dayak is an old literary work because tumet a poem performed at the wedding customs Ma'anyan tribes commonly called Wurung Jue, 2) acts of speech commonly used in ripple namely locutions and illocutionary speech acts. Riak also has characteristics in common with each stanza rhyme that these ripples consist of four lines with end rhymes $a-b-a-b$. Each array consists of four words or eight with the provisions of the first two lines are always in the form of figurative or sampiran, while the content or the exact meaning contained in the third and four lines.
\end{abstract}

\section{Keywords: Customery, Marriage, Speech Act.}

Culture is a way of life procedures that developed and shared by a group of people that are passed from generation to generation. Culture is made up of many elements of the complex, including the system of religion, politics, customs, languages, tools, clothing, buildings, and works of art. Cultural values that characterize the life of a community is usually contained in the written sources, oral and motion. Written sources can be either ancient texts. Source oral form of folklore, oral literature. While the source of motion manifested in activities such as folk games, traditional ceremonies be it a wedding ceremony, death, or other ceremonies. Society is a group of people organized, live and work together to achieve a goal. This means that communities have organizations and rules to relate to each other in everyday life. Society and culture can not be separated, both are interdependent concepts. Thus, society is a supporter of culture. A form of culture that form patterns of rule that grew and developed in the community will look at the implementation of the customs or traditions of the community. People who live in an area will automatically form or have norms, manners and rules.

Wurung Jue Jue or birds usually live in the mountains in the area Barito. This bird is a bird species that is most difficult to find and captured alive because it requires a special trick to catch it. In Ma'anyan Dayak community life in East Barito, this bird is emblematic of a fidelity, purity, majesty, of all things personal hygiene and vigilance against threats. 
These points are taken from the bird form Jue beautiful and graceful with unique properties. This bird has the properties faithful to the spouse, if the spouse dies see the pair of them will soon die, too well and therefore a symbol of fidelity is raised in the process of Customary Marriage and Lawangan Ma'anyan Dayak in East Barito currently.

At the time of Customary Marriage Event Process series, there is one event called wurung Jue, where Balian (shaman) was asked to look for the bride called Wurung Jue. In this process a few times Balian bringing a woman to ask whether this is really brought the couple sought by the groom, to get the right spouse. This is where loyalty was tested, because if the groom said it was true despite the fact not a couple who actually will be immediately decided that the couple brought is indeed true.

\section{Pragmatics}

Study of Pragmatic Pragmatics is a relatively new field of science that although Europe has grown in the 1940s and in the United States began developing in the 1970s. Growth in Europe begins with a view Morris in 1938 about semiotics. He divided the science of signs into three branches, namely syntax, semantics and pragmatics. The view was later received from other experts such as Halliday who in the 1960s developed a social theory of language with regard language as a social phenomenon. The development of this field in the United States was inspired by the work of philosophers who pay attention to language, namely Austin in 1962 and his Searle in the year 1969-1975. Austin wrote a book called How to Do Things with Word, he put forward the idea of performative and constative utterances. Another idea that is very important also is about the follow locutions, illocutionary, and perlokusi. Austin Searle forward thinking with his book Speech Acts: An Essay in the Philosophy of Language. In other works he found speech acts are not limited in number it can be categorized into five types, namely representative, directive, expressive, commissive, and declarations. Since the publication of two pragmatic pioneering work was bermuncullan other works in this field. Grice in 1975 sparked a theory of conversational implicature (conversational implicature).

The idea was published in an article entitled Logic and Conversation. Another important idea in the article is the principle of cooperation (cooperative principle), which is the principle that guides the conversation so that participants can conduct a conversation in a cooperative and can use the language effectively and efficiently. This principle is translated into four maxims, that maxim of quantity, quality, relevance, and how. In 1978, Brown and Levinson's politeness raised the issue with the notion that berkenaaan face, that face positive and negative face. In 1983 Leech published work entitled Principles of Pragmatics. Important literary ideas contained in this work, which is about politeness principle (politeness principle). Leech idea about the politeness with regard to the rules formulated in six maxims. Sixth maxim is the maxim of wisdom, acceptance, kindness, humility, suitability, and kesimpatian. Levinson (in Rahardi, 1983: 48) defines pragmatics as the study of language study language relation to its context. Parker (in Rahardi, 1986: 48) pragmatics is the branch of science that studies the structure of language externally. From the second definition above figures pragmaktik be concluded that a study is essential to win the meaning of language study, because the study of pragmatic assessment of the meaning to be attributed to the context. Studied in pragmatic meaning is bound to the context. Pragmatics examine the language to understand the intention of native speakers with considerations of context. 
Pragmatic assessment absolutely must be closely linked to the context of the situation said, this is in line with the theory of Leech (1993: 8) reveals that "pragmatics is the study of meaning and its relation with the situation said (speech situations)". According pragmatic study how language is used in 15 communication and pragmatics also investigate the meaning in context and not meaning as something abstract. Mey said of pragmatics as follows; "Pragmatics is the study of the conditions of humen language These are uses as determined by the context of society" (in Rahari, 1983: 49).

From the above, shall have the meanings linguistic pragmatics which studies language usage, basically always be determined by the context of the situation said in the society and culture that embodies rides and background. Context situations contemplated by Mey said as quoted by Rahardi the social context and the context sosiall. The social context is the context of language that arise as a result of the emergence of communication and interaction among members of the public with the socio-cultural background was very specific in nature. While the societal context is the context which is determined by the position of members of society in social institutions that exist in certain cultural and social society. On the front is already described that pragmatics is the study which bases its analysis of the context footing. Context means any background knowledge shared by speaker and hearer as well as accompanying and embody a speech. Based on an idea by Leech (1983: 13-14) that such a context that can be called by the context of the situation said, covers the following aspects: 1. The speaker and the person said (addressees) 2 . speech context 3. 4. speech as a destination said 5. The form of action or activity as the product of acts of verbal utterances. Then it is highly relevant research using a pragmatic assessment of pragmatic significance especially in actualizing the idea or ideas within the discourse.

Principles of Cooperation Keith Allan (in Rahardi, 1986: 52) tells is the social dimension of activities, such as other social activities. Speak could take place if the participants substitutions were actively involved in the process narrate. The communication process of the speaker and hearer can run well and smoothly, they have to cooperate with each other, for example by behaving politely to the other party. Behave is done by calculating the face of the hearer in activities narrate. In order for the message (message) to be well received in the participants said, the communication that occurs should consider the principles of (1) the principle of clarity (clarity), (2) the principle of density (conciseness), and the principle of continuity (directness). These three principles are fully embodied in four maxim cooperation Grice (1975) namely; (Maxim of quantity, quality maxim, maxim of relevance, and the maxim implementation.

\section{Speech Act}

Speech act is an entity that is central in the pragmatic and also the basis for the analysis of other topics in this field such presuppositions, perikutan, conversational implicature, cooperative principle and politeness principle. Rhetoric textual, pragmatic requires the cooperation principle. According Wijana (1996: 46) to implement the principle of cooperation, the speakers must adhere to the four maxims of conversation, ie the maxim of quantity, quality, relevance, and execution. Maksim quantity requires every participant substitutions contributed enough or as much as needed by the other. Maksim quality conversation requires each participant to tell the truth. Maksim implementation requires each participant conversation to speak directly, not vague, ambiguous, and it is no 
exaggeration, as well as coherent. Meanwhile, Austin (in Leech, 1993: 280) states that all speech is a form of action and not just something about the world of speech acts or speech (speech act) is a function of language as a means of penindak. All of the sentence or utterance spoken by the speaker actually contains specific communicative functions. Based on these opinions can be said to utter something that can be called as aktivias or action. This is possible because in every speech has a specific purpose that effect on others. Based on the above opinion can be concluded that the speech act is the activity by telling something. Speech acts that have a specific purpose can not be separated from the concept of the situation said. The concept clarify the concept of speech act as an act that produces speech as a speech act products.

\section{Classification Of Speech Acts}

Understanding some of the Follow-Speech (classification of speech acts)

1. speech acts locutions

Locutions speech acts are acts of saying something with words and sentences according to the meaning in the dictionary, and according to the rules of syntax. Follow-locutions are speech acts to express something. Speech act is often referred to as The Act of Saying Something. Focus locutions is the meaning of spoken utterances, not questioning the purpose or function of the speech.

2. speech acts illocutionary

The follow is illocutionary speech act that serves to tell or inform something and used to do something. Illocutionary speech act is a speech act related to the purpose intended by the speaker. Follow-illocutionary also referred to as the Act of Doing Something. Illocutionary a speech act that had the purpose and function or power of speech. Questions were raised regarding the illocutionary acts is "to what the speech is done" and is no longer at the level of "what the meaning of that speech?

Classification of Speech Acts illocutionary

a. Representative speech acts

Representative speech act is a speech act that binds speakers of the truth of something uttered. Which belong to the kind of speech acts are speech-speech states, demanding, recognize, report, show, said, testifying, and speculate.

b. Directive speech acts

Directive speech act is a speech act performed by the speaker with the intention that the hearer do the actions mentioned in the speech. Speech-speech that included the type of directive speech acts are: force, invite, solicit, send, collect, urging, pleading, suggest, govern, gestured, and challenging.

c. Expressive speech acts

Expressive speech act is uttered speech acts the speaker intended as an evaluation of the things mentioned in the speech. Which include the type of speech acts are speech-speech praising, say thank you, criticize, complain, blame, congratulate, danmenyanjung.

d. Speech acts commissive

Commissive speech act is a speech act that binds speakers to implement something that is mentioned in tuturannya. Speech which included the type of speech acts commissive is promise, swear, threaten, denial and stated readiness.

e. Speech acts declaration 
Speech acts speech acts declaration is intended speakers to create it (status, state, and so on) are new. Speech-speech with the intention of ratifying, decided to cancel, bans, permits, grants, lifting, classify, forgive, and memaafkantermasuk declaration of speech acts.

3. Speech acts perlokusi

Perlokusi speech acts speech acts pengujarannya is intended to influence the hearer. Tin $\neg$ dak perlokusi referred to as The Act of Affecting Someone. A person's speech expressed often have the power to influence or effect that men $\neg$ dengarnya. The effect of this can be purposefully or not se $n$ naja. Pengujaran speech acts intended to influence the hearer is a follow perlokusi.

Understanding some of Strategy Follow-Speech

(Classification Strategy Follow-Speech)

a. Direct speech act

Formally direct speech act, based on the modus sentence is divided into news sentences (declarative), interrogative sentence (introgatif), and imperative sentences (imperative). Conventionally sentence news used to give something (information), interrogative sentence to ask for something, and imperative sentences to express orders, invitations, requests, and requests.

b. Indirect speech acts

Indirect speech acts are different utterances by the sentence mode and adapted to the context that follows. For example, the sentence of news that should serve to proclaim something can be used to ask or tell. Likewise interrogative sentence which should serve to ask something can be used to request or send

c. Speech acts are not literal

Speech acts are not the same or opposite meaning to the words that constitute it.

d. Direct speech acts literal

Direct speech acts literal speech acts are expressed in speech mode and the same meaning with the intent pengutaraannya. Intention to rule submitted by the sentence order, proclaiming the news sentences, and ask something with interrogative sentence.

e. Indirect speech acts literal

Indirect speech acts speech acts literal is expressed by the sentence mode that does not comply with the intent pengutaraannya, but the meanings of words are arranged according to what is intended by the speaker.

f. Direct speech acts are not literal

Direct speech acts are not literal speech acts expressed by the sentence mode consistent with the intent and speech, but the words of which it is composed do not have the same meaning for the purpose of its speakers.

g. Indirect speech acts are not literal

Indirect speech acts are not literal speech acts expressed by the sentence mode that does not comply with the purpose to be expressed.

\section{Riak In Wurung Jue}

Why Dayak wear jue bird as a bird indigenous tradition is because this one is characteristic in Kalimantan, in addition to hunting these birds are beautiful, the behavior of these birds that makes the symbols in marriage Dayak. This bird is emblematic of a fidelity, purity, majesty, of all things personal hygiene and vigilance against threats. This 
bird is faithful to his spouse. On "nyama wurung jue" is actually the culmination of marriage Dayak Maanyan that ends with a "pillar trowel", even this event was the show's most intriguing because the Wadian will perform the show - a show that attractive as "namuan mountain slut" and in cover with "Wadian round" event nyama wurung jue actually to look for the bride, the groom who came to seek his bride. Task Wadian is to find a bride, there will be five women who will be paired with the groom until the last bride original finds, usually of couples Mining, up to four in the capture of spectators who came (from children, adolescents, mother - a mother and grandmother grandmother, as long as a woman). Then the last one is the bride is the actual or wurung jue truth, for the purpose of the event wurung jue nyama is to find the female spouse of the groom.

Nyama wurung jue customary ritual is witnessed by mantir mantir pangulu customs and the customs along with the families of both the bride and the spectators who come. The next event is the fulfillment of customary law and pillar trowel.

\section{METHODS}

Before conducting the study, researchers must determine the research methods to be used. This is important because it helps determine whether or not achieved the purpose of research which will be carried out. Emzir (2010: 6) states "qualitative descriptive research, ie testing incentives. Data collected over take the form of words or pictures instead of numbers. "The purpose of descriptive research is to increase knowledge about the events of contemporary real communication context. By using descriptive emphasizes more real picture on a study that observed with the aim of knowing the widest on the object of research through data acquisition and delivery informasiBerdasarkan above opinion and research objectives to be achieved in this study the authors use the method of descriptive qualitative, ie methods depicting and describing a situation as it is in accordance with the present or occur in a real situation. While the data are being used to obtain documentation, namely the record and noting the riaks in the wedding ceremony.

\section{Riak Dayak Ma'anyan}

\section{DISCUSSION}

Riak Dayak Ma'anyan is a custom made by the Dayak Ma'anyan in any traditional wedding or an activity commonly referred to Wurung Jue. In the event there is a riak commonly spoken by healers companion event. The riaks could also be described as the utterances containing the meaning and the message therein.

Riak Dayak Dayak Ma'anyan different from the others, because the riak Dayak Ma'anyan the form of a poem that uses language Ma'anyan. Riak is this habit is also commonly used in dance performances that serves as a substitute for the ritual words. Dayak riak Ma'anyan have the same pattern with a rhyme. Each stanza riak consists of four lines with end rhymes a-b-a-b. Each array consists of four words or eight with the provisions of the first two lines are always in the form of figurative or sampiran, while the content or the exact meaning contained in the third and four lines.

Examples riak commonly used in Wurung Jue, namely:

Ni papan raga-raga 
Anak umpis isa ngaun salai

Surung senu ita jukung jawa

Kapipi umak lali lalai.

\section{Speech Acts Found In Riak Dayak Ma'anyan}

Speech act as we know there likusi speech acts, illocutionary speech acts and speech act perlokusi. In riak Dayak Ma'anyan sometimes there is a speech act in it, like the riaks that give information. An information that we can get the riak usually is on the third and fourth lines is the content.

A typical speech acts on the riak Dayak Ma'anyan is speech act locutions. Locutions speech act is a speech act that conveys information to the opponent a speech or others directly. In riak Dayak Ma'anyan speech acts locutions usually occurs in riaks.

Example:

Sit lengan mungsit

Tudi hang kakau kayu

Na'an duitku babutit

Pakai midi baju wa'u

This means:

The sound of birds mungsit

Perched in a tree

There is a bit of my money

To buy new clothes

In this riak, there is a speech act locutions. The rhyme in the third and fourth lines stating that there is very little money. Then the poem there is also a illocutionary speech acts on the third and fourth lines show bahnwa he did not have money and want to buy new clothes.

Riak included in pragmatic action because it is usually in the event Wurung Jue, the riaks do blared with others. So the riaks can be regarded as a conversation conducted in the form of a long literary works that rhyme. This habit is the same as is the custom in tribal betawi also blared rhymes.

\section{CONCLUSION}

Dayak Ma'anyan riak is an old literary work because tumet a poem performed at the wedding customs Ma'anyan tribe commonly referred to Wurung Jue. Speech acts are used in riak namely locutions and illocutionary speech acts. Riak also has characteristics in common with each stanza rhyme that consist of four lines with end rhymes a-b-a-b. Each array consists of four words or eight with the provisions of the first two lines are always in the form of figurative, while the content or the exact meaning contained in the third and four lines.

\section{REFERENCES}

Cutting, Joan. 2002. Pragmatics and Discourse: A Resource Book for Students. New York: Routledge

Kridalaksana, Harimurti. 2007. Pengantar (Metode) Penelitian Bahasa. Yogyakarta: Carasvatibooks. 
Leech, Geoffrey. 1991. Principle of Pragmatics. London: Longman

Levinson, Stephen C. Pragmatics. Cambridge: Cambridge University Press, 2008.

Moleong, Laxy J. 2010. Metodologi Penelitian Kualitatif. Bandung: Remaja Rosdakarya.

Rahardi, Kunjana. 2005. Pragmatik: Kesantunan Imperatif Bahasa Indonesia. Jakarta: Penerbit Erlangga

Wijana, I Dewa Putu. 1996. Dasar-dasar Pragmatik. Yogyakarta: Penerbit Andi

Yule, George. 2006. Pragmatik (terjemahan Indah Fajar Wahyuni). Yogyakarta: Pustaka Pelajar. 